\title{
Pemanfaatan Ikan Nila Sebagai Produk Kuliner Khas Ekowisata Bendhung Lepen Yogyakarta
}

\author{
Cita Eri Ayuningtyas', Yunda Maymanah Rahmadewi ${ }^{2}$, Agung Budiantoro ${ }^{3}$ dan M. Rasyid Ridha ${ }^{4}$ \\ 1,2,4Program Studi Bisnis Jasa Makanan, Fakultas Ekonomi dan Bisnis, Universitas Ahmad Dahlan \\ Yogyakarta, Jl. Pramuka No. 42, Pandeyan Kec. Umbulharjo, Kota Yogyakarta Daerah Istimewa Yogyakarta \\ Indonesia 55161 \\ ${ }^{3}$ Program Studi Biologi, Fakultas Matematika dan Ilmu Pengetahuan Alam, Universitas Ahmad Dahlan \\ Yogyakarta, Jl. Ring Road Selatan, Tamanan Banguntapan, Bantul Yogyakarta, Indonesia 55166
}

Correspondence: Cita Eri Ayuningtyas (cita.eri@culinary.uad.ac.id)

Received: 30 Juni 2021 - Revised: 01 Agustus 2021 - Accepted: 16 Agustus 2021

\begin{abstract}
Abstrak. Bendhung Lepen merupakan salah satu destinasi wisata di Kota Yogyakarta yang menyajikan daya tarik budidaya ikan nila yang memanfaatkan aliran irigasi. Potensi ikan nila belum dimanfaatkan secara maksimal di wilayah ini. Ikan nila yang dipanen secara periodik hanya dijual pada warga sekitar. Padahal ikan nila merupakan ikan yang mudah dibudidayakan dan jumlah produksinya melimpah. Pengolahan ikan nila selama ini masih terbatas pada menu makan besar, seperti digoreng, dibakar atau hidangan berkuah. Olahan yang variatif dan juga kekinian dibutuhkan untuk mengolah ikan nila agar dapat dijadikan produk kuliner khas di area ini. Berdasarkan data di lapangan, jajanan di wilayah ini belum begitu variatif dan belum memanfaatkan ikan nila sebagai produk kulinernya. Hal ini disebabkan salah satunya adalah pengetahuan dan ketrampilan masyarakat setempat. Tujuan dari pelatihan ini diharapkan dapat meningkatkan ketrampilan dalam mengolah ikan nila menjadi produk kuliner khas Bendhung Lepen. Metode yang dilakukan yaitu berupa pelatihan olahan pangan. Hasil pelatihan berupa peningkatan pengetahuan dan ketrampilan mitra sebesar $80 \%$ pada pengalaman mengolah produk. Produk olahan yang berbasis ikan nila yang terdiri dari produk makanan yang dibekukan atau frozen food dan juga cemilan kering yaitu rolade, nugget, otak-otak, fish katsu, stik ikan dan krupuk kulit.
\end{abstract}

Kata kunci: Pelatihan Olahan, Ikan Nila, Kuliner

Citation Format: Ayuningtyas, C.E., Rahmadewi, Y.M., Budiantoro, A.\& Ridha, M.R. (2021). Pemanfaatan Ikan Nila Sebagai Produk Kuliner Khas Ekowisata Bendhung Lepen Yogyakarta. Prosiding Seminar Nasional Abdimas Ma Chung (SENAM), 65-74. 


\section{PENDAHULUAN}

Bendhung Lepen merupakan salah satu lokasi wisata yang ada di Kota Yogyakarta. Wilayah ini memanfaatkan aliran irigasi sebagai tempat budidaya ikan nila yang dijadikan daya tarik untuk wisatawan (Pradana, 2020). Potensi ikan nila di daerah ini belum dimanfaatkan secara maksimal. Ikan nila yang dibudidaya di area ini setiap 3-4 bulan akan dipanen kemudian dijual ke warga. Pada tahun 2020, sebanyak $2354 \mathrm{~kg}$ ikan nila dipanen dan dijual dengan harga Rp. 27.500,- per kilo nya (Anonim, 2020).

Potensi yang cukup besar ini dapat dimanfaatkan oleh warga sekitar tanpa harus menunggu masa panen. Ikan nila merupakan ikan air tawar yang mudah dalam budidaya (Andre, 2021). Selain itu, rasa daging yang gurih serta pengolahan yang mudah menjadikan ikan ini menjadi menu andalan dalam rumah makan. Di sisi lain, komoditas ikan merupakan bahan makanan yang mudah mengalami kerusakan, sehingga tidak dapat bertahan lama ketika sudah mati.

Ikan dapat mengalami kerusakan apabila tidak segera diolah. Hal ini dikarenakan ikan merupakan bahan yang mudah busuk. Apabila sudah terjadi kerusakan, maka tubuh ikan akan berlendir, mata keruh, dagingnya lunak, dan biasanya sisik mudah terkelupas (Ndahawali, 2016). Salah satu cara yang dapat dilakukan agar ikan tidak mengalami kerusakan lebih lanjut yaitu dengan pengolahan. Selama ini pengolahan masih terbatas pada menu ikan goreng, bakar atau dibuat dalam hidangan berkuah. Sedangkan apabila musim panen tiba, dibutuhkan olahan lain yang dapat meningkatkan daya simpan ikan yang lebih lama. Di samping itu, olahan yang selama ini belum dapat dikatakan bervariasi.

Ikan nila memiliki kandungan gizi yang cukup baik untuk memenuhi kebutuhan gizi sehari-hari. Kandungan protein dalam ikan nila berada pada rentang 12,94-16,79 gram per 100 gram ikan nila. Selain itu, kandungan mineral zat besi dan fosfor termasuk tinggi. Ikan nila mengandung lemak sekitar 0,10-0,18 gram (Ramlah et al., 2016). Selain kandungan gizi yang cukup baik, ikan memiliki protein yang mudah dicerna dibandingkan produk hewani lain (Kresna D, 2017).

\section{MASALAH}

Berdasarkan data yang ada di lapangan dan hasil proses observasi, diketahui bahwa wilayah wisata Bendhung Lepen di Mrican Umbulharjo ini masih kurang dalam hal pengolahan ikan sebagai produk kuliner khas dari tempat ini. Selain itu, variasi jajanan yang dijual juga belum banyak. Jajanan yang dijual di area wisata ini justru tidak ada yang dibuat 
dari ikan nila, padahal potensi ikan nila sebagai makanan ataupun oleh-oleh khas dari area wisata ini cukup besar. Di samping itu, ikan nila dapat digunakan sebagai salah satu alternatif makanan di era adaptasi baru.

Ikan nila merupakan ikan air tawar yang murah dan melimpah. Rasa ikan yang gurih membuat ikan ini cukup favorit di masyarakat (Kaswanto et al., 2019). Namun di sisi lain, ikan nila masih belum banyak diolah menjadi olahan yang memiliki masa simpan yang panjang. Ikan merupakan salah satu bahan makanan yang mudah rusak, sehingga perlu adanya teknik pengolahan yang tepat agar dapat disimpan lebih lama sebelum dikonsumsi.

Pengolahan ikan menjadi olahan frozen food memang sudah banyak dilakukan, namun masih terbatas terutama pada jenis ikan tawar. Pengolahan ini menjadi salah satu alternatif yang bisa digunakan untuk menjadikan produk makanan dapat disimpan lebih lama pada mesin pendingin dan diolah lebih lanjut. Pembekuan merupakan salah satu teknik pengawetan makanan yang dilakukan dengan menurunkan suhu pada produk makanan pada suhu beku yang diinginkan (Hariyadi, 2007). Produk frozen food yang dibuat dari bahan dasar protein antara lain nugget, bakso, otak-otak, dll. Produk ini banyak diminat seiring dengan perkembangan jaman dan juga adanya kebutuhan makanan yang memiliki daya simpan yang lama pada era adaptasi baru.

Kondisi masyarakat mitra masih belum mengenal olahan ikan nila yang dapat dijadikan menjadi produk frozen food. Selain itu, pengetahuan pemanfaatan ikan hanya sebatas pada dagingnya saja. Sehingga program yang dapat diusung di sini adalah pelatihan pembuatan produk pangan olahan berbasis ikan nila yang dibuat dengan memanfaatkan seluruh bagian tubuh ikan nila dari kepala sampai ekor menjadi olahan beku ataupun cemilan kering.

\section{METODE PELAKSANAAN}

Program Pengabdian ini dilakukan di Pendopo Bendhung Lepen Mrican Umbulharjo Yogyakarta dengan tetap melaksanakan protokol kesehatan yang ketat seperti menggunakan masker dan menjaga jarak, serta menjaga kebersihan tangan. Pelaksanaan kegiatan dilakukan dengan pelatihan pembuatan produk. Kegiatan ini dilakukan dalam beberapa tahapan seperti berikut ini :

1. Sosialisasi Program : Sosialisasi program dilaksanakan pada tanggal 11 Juni 2021. Kegiatan sosialisasi program dilakukan dengan menjabarkan kegiatan pelatihan serta tujuan diadakannya pelatihan pembuatan produk. Kegiatan ini dihadiri oleh 
peserta pelatihan dan juga pengurus wisata setempat. Selama kegiatan berlangsung, pengusung program memaparkan kegiatan yang akan dilaksanakan. Selain itu, dalam kegiatan ini juga dibuka diskusi tanya jawab dan juga fiksasi jadwal pelatihan.

2. Pembekalan pembuatan produk pada training : Kegiatan pembekalan dilakukan untuk melatih mahasiswa dalam pembuatan produk. Tujuan dari kegiatan ini adalah menyamakan persepsi dengan mahasiswa terkait dengan standar resep produk yang akan dibuat. Kegiatan pembekalan dilakukan di Laboratorium Cooking 2 Program Studi Bisnis Jasa Makanan Universitas Ahmad Dahlan.

3. Pembelian peralatan dan bahan pelatihan : Kegiatan ini dilakukan dengan mempersiapkan bahan yang dibutuhkan dalam pelatihan seperti ikan, tepung, bumbu, minyak dan telur. Sedangkan peralatan yang dibutuhkan seperti kukusan, wajan, kompor, food chooper, pisau, talenan, nampan, dll. Peralatan akan didistribusikan ke lokasi pelatihan untuk digunakan peserta selama pelatihan.

4. Pelatihan pembuatan produk : Pelatihan pembuatan produk dilakukan pada tanggal 23 Juni 2021 di area Pendopo Bendhung Lepen. Peserta yang ikut dalam pelatihan berjumlah 10 orang yang merupakan ibu-ibu pedagang di wilayah setempat. Peserta dibagi menjadi dua kelompok yang akan dipandu oleh satu mahasiswa pada setiap kelompoknya. Pada awal kegiatan, peserta akan dipandu oleh tim pengusung program untuk mengisi kuesioner pre test dan setelah pelatihan kembali diberikan kuesioner post test sebagai alat pengukuran tingkat pengetahuan saat sebelum dan sesudah diadakannya pelatihan. Produk yang dibuat berjumlah 6 jenis, yaitu otak-otak ikan nila, nugget ikan nila, rolade ikan nila, fish katsu, kerupuk kulit ikan nila dan stik ikan nila. Pelatihan dilakukan dari penyiapan bahan, pengolahan hingga pengemasan produk. Pada pelatihan ini juga diberikan modul yang dapat dijadikan acuan peserta dalam pembuatan produk selama pelatihan.

\section{HASIL DAN PEMBAHASAN}

Kegiatan pelatihan yang dilakukan di masyarakat mitra, diketahui bahwa jumlah peserta yang mengikuti pelatihan olahan yaitu sebanyak 10 orang. Peserta merupakan ibuibu di wilayah Bendhung Lepen yang sehari-hari bekerja sebagai pedagang dan ada pula yang tidak bekerja. Hasil pelatihan diukur dengan menggunakan kuesioner untuk 
mengetahui peningkatan pengetahuan. Pelatihan dilakukan pada tanggal 23 Juni 2021 dengan durasi waktu kurang lebih 5 jam. Pelatihan di awali dengan menjelaskan teknis pelatihan yang akan dilakukan, pembagian modul pelatihan, pembagian kelompok, kemudian membagikan soal pretest pada peserta.

Tabel 1. Karakteristik Peserta Pelatihan

\begin{tabular}{|c|c|c|c|}
\hline \multirow[t]{2}{*}{ No } & \multirow{2}{*}{ Aspek } & \multicolumn{2}{|c|}{ Jumlah Peserta } \\
\hline & & & Persentase \\
\hline \multirow[t]{3}{*}{1} & Jenis Kelamin & & \\
\hline & Laki-laki & 0 & 0 \\
\hline & Perempuan & 10 & $100 \%$ \\
\hline \multirow[t]{3}{*}{2} & Pekerjaan & & \\
\hline & Pedagang & 5 & $50 \%$ \\
\hline & Ibu rumah tangga & 5 & $50 \%$ \\
\hline \multirow[t]{4}{*}{3} & Pengalaman mengolah ikan & & \\
\hline & menjadi frozen food & & \\
\hline & Sudah pernah & 2 & $20 \%$ \\
\hline & Belum pernah & 8 & $80 \%$ \\
\hline
\end{tabular}

Karakteristik peserta dapat dilihat pada tabel 1. Sebagian besar peserta belum pernah mendapatkan pengalaman mengolah ikan menjadi produk frozen food sebelumnya. Hal ini dapat dilihat dari jumlah peserta yang sudah ada pengalaman mengolah hanya dua orang (20\%). Hal ini menjadi dasar pengukuran sebelum dilakukannya pelatihan olahan.

Berdasarkan hasil pengukuran dari kuesioner sebelum dan sesudah pelatihan, diketahui bahwa terjadi peningkatan pada aspek pengetahuan. Aspek ini meliputi pengalaman mengolah ikan, pengetahuan mengenai pengolahan frozen food, produk frozen food dan juga bahan dasar yang digunakan. Poin terbesar meningkat pada aspek pengalaman mengolah ikan yaitu sebesar 16 poin atau sebesar $80 \%$. Sedangkan pada aspek pengetahuan mengenai frozen food terkait pengolahan meningkat sebesar 9 poin, terkait dengan produk meningkat sebesar 3 poin, dan pengetahuan bahan dasar sebesar 8 poin. Hasil pengukuran sebelum dan sesudah pelatihan dapat dilihat pada tabel 2 berikut ini : 
Tabel 2. Peningkatan Pengetahuan Sebelum dan Sesudah Pelatihan

\begin{tabular}{llcccc}
\hline No & \multicolumn{1}{c}{ Aspek } & $\begin{array}{c}\text { Hasil rerata nilai }(\mathrm{n}=10) \\
\text { Sebelum } \\
\text { pelatihan }\end{array}$ & $\begin{array}{c}\text { Sesudah } \\
\text { pelatihan }\end{array}$ & $\begin{array}{c}\text { Peningkatan } \\
\text { Skor }\end{array}$ & Persentase \\
\hline 1 & $\begin{array}{l}\text { Pengalaman mengolah ikan } \\
2\end{array}$ & 4 & 18 & 16 & $80 \%$ \\
$\quad \begin{array}{l}\text { Pengetahuan mengenai } \\
\text { pengolahan frozen food }\end{array}$ & 18 & 27 & 9 & $30 \%$ \\
3 & $\begin{array}{l}\text { Pengetahuan produk frozen } \\
\text { food }\end{array}$ & 15 & 18 & 3 & $15 \%$ \\
4 & Pengetahuan bahan dasar & 20 & 28 & 8 & $27 \%$ \\
\hline
\end{tabular}

Pelatihan memiliki tujuan antara lain meningkatkan ketrampilan seseorang dalam bidang tertentu untuk meningkatkan efektifitas dan juga produktifitas. Pelatihan erat kaitannya dengan unsur pendidikan, sehingga dalam kegiatan pelatihan ada proses pembelajaran yang dapat mengembangkan potensi seseorang dengan cara meningkatkan pengetahuan, ketrampilan dan juga nilai/sikap (Efendi, 2017). Kegiatan pelatihan ini diisi dengan membuat produk olahan berbasis ikan nila menjadi olahan frozen food dan juga cemilan kering. Pengetahuan dan ketrampilan mitra meningkat setelah dilakukan program pelatihan olahan ini, seperti pengalaman mengolah yang meningkat sebesar $80 \%$.

Pada kegiatan pelatihan ini, produk olahan yang dibuat antara lain nuget ikan nila, otak-otak ikan, rolade ikan, fish katsu, stik ikan dan kerupuk kulit ikan. Bagian daging ikan diolah menjadi rolade, otak-otak, fish katsu, dan nuget. Sementara untuk tulang atau duri dan juga kepala diolah menjadi stik ikan. Bagian kulit ikan tidak terbuang melainkan diolah menjadi kerupuk kulit ikan yang dibumbui dengan bumbu rendaman. Hasil olahan langsung dikemas dalam kemasan kedap udara sebagai simulasi kemasan produk ketika dijual.

Pada pelatihan ini, empat produk merupakan produk yang dibekukan. Sedangkan dua produk lainnya merupakan produk cemilan kering. Ikan nila merupakan ikan yang mudah dibudidayakan dan juga masa panen yang singkat (Andre, 2021). Di sisi lain, ikan ini menjadi ikan air tawar yang banyak diminati masyarakat karena rasa yang gurih, namun pengolahan masih terbatas pada olahan masakan lauk atau sayur. Hampir semua daerah di Indonesia membudidayakan ikan ini dan hasil produksinya cukup tinggi per tahunnya (BPS, 2018). 


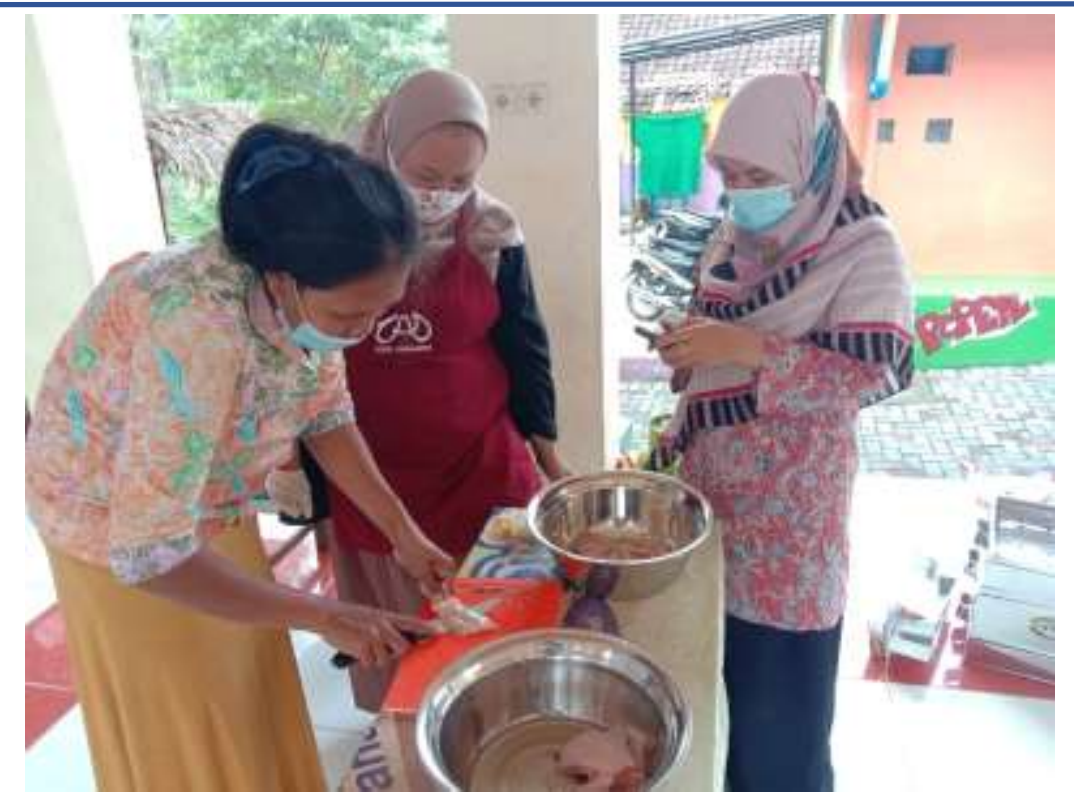

Gambar 1. Kegiatan Pelatihan Olahan Berbasis Ikan Nila

Kegiatan pelatihan dilakukan dengan membagi kelompok menjadi dua. Masingmasing kelompok akan didampingi oleh satu mahasiswa. Kelompok pertama mendapatkan olahan rolade, fish katsu dan juga kerupuk kulit ikan. Sedangkan yang kelompok kedua mendapatkan olahan otak-otak, nugget, dan stik ikan. Kedua kelompok akan saling berdiskusi ketika pelatihan dan menjelaskan satu sama lain proses pengolahan ikan. Mahasiswa yang berperan sebagai tim yang memandu menjelaskan proses pengolahan ikan.

Olahan ikan nila dibuat menjadi produk yang dibekukan bertujuan agar memiliki daya simpan yang relatif panjang. Penyimpanan makanan dalam suhu $-18^{\circ} \mathrm{C}$ dapat mencegah kerusakan produk dengan menghambat pertumbuhan bakteri (Sitakar et al., 2016). Nugget merupakan salah satu produk frozen food yang diminati di masyarakat. Nugget merupakan produk olahan yang dibuat dari daging sapi, daging ayam atau ikan. Nugget dibuat sebagai produk lauk setengah jadi. Selain praktis, nugget memiliki kandungan protein yang cukup untuk memenuhi kebutuhan gizi per hari (Fona et al., 2017). Hasil pelatihan dapat dilihat pada gambar 2 . 


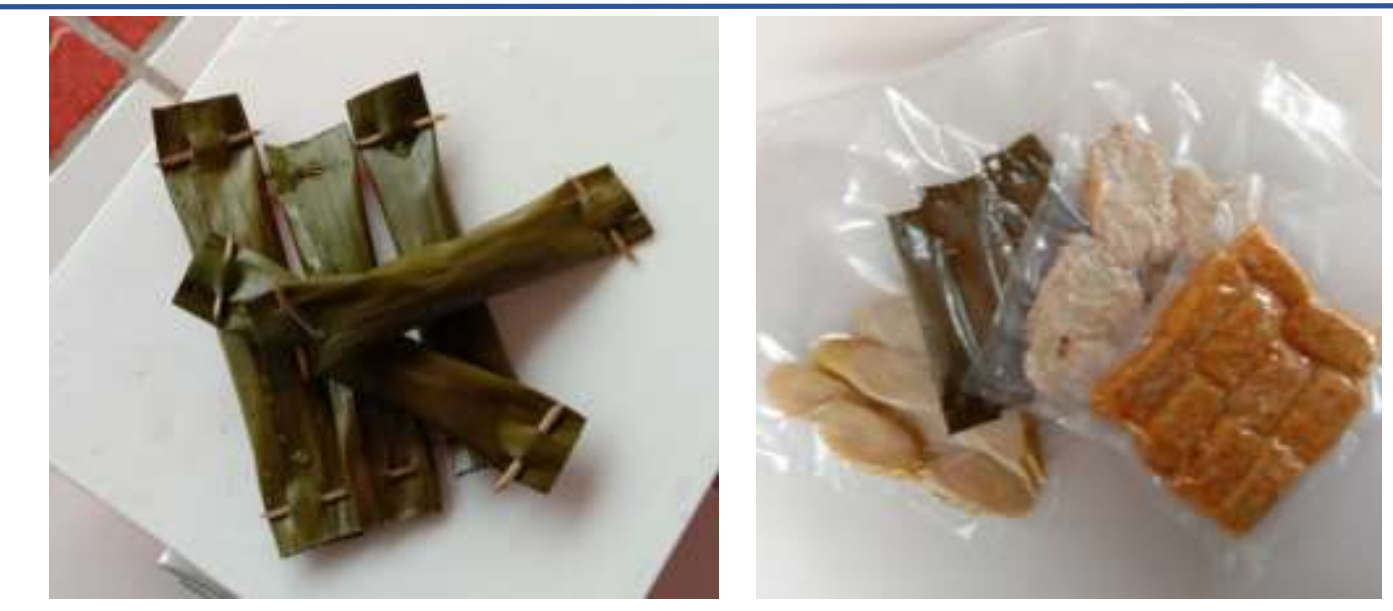

Gambar 2. Hasil Pelatihan Berupa Produk Olahan Berbasis Ikan Nila

Output dari pelatihan ini adalah adanya produk berupa olahan ikan nila yang berupa produk yang dibekukan dan produk cemilan kering. Harapan yang diinginkan dari pelatihan ini, produk tersebut dapat menjadi olahan khas yang dihasilkan dari Bendhung Lepen sebagai upaya memanfaatkan hasil budidaya ikan nila di area wisata Bendhung Lepen. Lebih jauh lagi, olahan ini dapat menjadi oleh-oleh yang dikembangkan oleh masyarakat di ekowisata Bendhung Lepen.

\section{KESIMPULAN}

Berdasarkan kegiatan yang telah dilakukan, terdapat peningkatan pengetahuan dan ketrampilan sesudah adanya pelatihan pengolahan produk berbasis ikan nila. Hal ini dapat dilihat pada skor sesudah pelatihan yang mengalami kenaikan dibandingkan sebelum pelatihan yang meningkat sebesar $80 \%$ pada pengalaman mengolah. Selain itu, didapatkan produk luaran berupa produk olahan yang berupa produk makanan beku yaitu rolade ikan nila, nugget, fish katsu, dan otak-otak. Sementara produk cemilan kering berupa stik ikan nila dan juga kerupuk kulit ikan. Rekomendasi untuk masyarakat mitra agar dapat memaksimalkan hasil panen ikan untuk dijadikan produk oleh-oleh khas Bendhung Lepen.

\section{UCAPAN TERIMA KASIH}

Ucapan terima kasih kami sampaikan kepada Kemenristek BRIN yang telah memberikan kesempatan pada penulis untuk menerima pendanaan Hibah PKM Tahun 
Anggaran 2021. Penulis juga menyampaikan pada masyarakat yang telah ikut serta dalam program ini.

\section{DAFTAR PUSTAKA}

Andre, H. (2021). Budidaya Ikan Nila Ala Wakil Ketua BPD Tamannartani. JOGJADAILY. https://jogjadaily.com/2021/05/budidaya-ikan-nila-ala-wakil-ketua-bpdtamanmartani/

Anonim. (2020). Panen Ikan Nila di Bendung Lepen Mrican Giwangan. Kelurahan Giwangan. https://giwangankel.jogjakota.go.id/detail/index/12329

BPS. (2018). Nilai Produksi Perikanan Budidaya Menurut Komoditas Utama (Ribu Rupiah), 2017. Badan Pusat Statistik. https://www.bps.go.id/indicator/56/1514/1/nilai-produksiperikanan-budidaya-menurut-komoditas-utama.html

Efendi, Y. K. (2017). Pelaksanaan Program Pendidikan Pelatihan Di Dinas Tenaga Kerja Transmigrasi dan Kependudukan Pemerintah Propinsi Jawa Timur. Khazanah Pendidikan, X(2), 1-18.

Fona, Z., Kurniasih, E., \& Raudah, . (2017). Pengembangan Unit Usaha Nugget Sehat di Politeknik Negeri Lhokseumawe. Agrokreatif Jurnal Ilmiah Pengabdian Kepada Masyarakat, 3(2), 115. https://doi.org/10.29244/agrokreatif.3.2.115-122

Hariyadi, P. (2007). Teknologi Pembekuan Pangan. Food Review Indonesia, II(7), 30-35.

Kaswanto, I. N., Desmelati, \& Dewita, A. D. (2019). Karakteristik Fisiko-kimia dan Sensori Kerupuk Pangsit dengan Penambahan Tepung Tulang Nila (Oreochromis niloticus). Jurnal Agroindustri Halal, 5(2), 141-150.

Kresna D, A. (2017). Mengenal Kandungan Gizi Pada Ikan. DKP Provinsi Jateng. https://dkp.jatengprov.go.id/index.php/artikel/bidangpukp/mengenal-kandungan-gizipada-ikan

Ndahawali, D. H. (2016). Mikroorganisme Penyebab Kerusakan Pada Ikan dan Hasil Perikanan Lainnya. Buletin Matric, 13(2), 17-21.

Pradana, A. (2020, October). Bendhung Lepen, dari selokan penuh limbah jadi destinasi wisata di Yogyakarta. BBC News Indonesia. https://www.bbc.com/indonesia/media54600957

Ramlah, Soekendarsi, E., Hasyim, Z., \& Hasan, M. S. (2016). Perbandingan Kandungan Gizi Ikan Nila Oreochromis niloticus Asal Danau Mawang Kabupaten Gowa dan Danau Universitas Hasanuddin Kota Makassar. Jurnal Biologi Makassar (Bioma), 1(1), 3946.

Sitakar, N. M., Jamin, F., Abrar, M., Manaf, Z. H., Nurliana, \& Sugito. (2016). Pengaruh Suhu Pemeliharaan dan Masa Simpan Daging Ikan Nila (Oreochromis niloticus) pada Penyimpanan Suhu -20oC Terhadap Jumlah Total Bakteri. Jurnal Medika Veterinaria, 10(2), 162-165. 
(c) (i)

(C) 2021 by authors. Content on this article is licensed under a Creative Commons Attribution 4.0 International license. (http://creativecommons.org/licenses/by/4.0/). 